Man and Nature

L'homme et la nature

\title{
Natural Law and the Scottish Enlightenment
}

\section{Knud Haakonssen}

Volume 4, 1985

URI : https://id.erudit.org/iderudit/1011836ar

DOI : https://doi.org/10.7202/1011836ar

Aller au sommaire du numéro

Éditeur(s)

Canadian Society for Eighteenth-Century Studies / Société canadienne d'étude du dix-huitième siècle

ISSN

0824-3298 (imprimé)

1927-8810 (numérique)

Découvrir la revue

Citer cet article

Haakonssen, K. (1985). Natural Law and the Scottish Enlightenment. Man and Nature / L'homme et la nature, 4, 47-80. https://doi.org/10.7202/1011836ar

Copyright (c) Canadian Society for Eighteenth-Century Studies / Sociéte canadienne d'étude du dix-huitième siècle, 1985
Ce document est protégé par la loi sur le droit d'auteur. L'utilisation des services d’Érudit (y compris la reproduction) est assujettie à sa politique d'utilisation que vous pouvez consulter en ligne.

https://apropos.erudit.org/fr/usagers/politique-dutilisation/ 


\section{Natural Law and the Scottish Enlightenment}

Natural law ideas are a well known feature of both ancient and medieval thought, and it has always been a popular scholarly pastime to debate where the 'modern' school of natural law begins - a particular favourite being the question whether Hugo Grotius was the last of the scholastics or the first of the moderns. Much of this debate is fruitless, but it has nevertheless made clear that there is a range of issues over which Grotius' standpoints can be seen to set the course for the future, even though it may be possible to find more or less clear scholastic antecedents for some of them. ${ }^{1}$ And even if Grotius had been entirely unoriginal, it would still be to him that the historian of ideas would have to turn in order to understand modern natural law theory. For during the one-anda-half centuries or more during which such theory was prevalent, and often dominant, in Europe, it was Grotius' formulations which formed the starting-point; it was he who was seen as the originator of something new.

Now although Grotius is occasionally adopted as an honorary German - as e.g. in Erik Wolf's classic Grosse Rechtsdenker der deutschen Geistesgeschichte - we should remember that he was Dutch, and this not just for the sake of national sensibilities. For apart from his extraordinary personal career, it was the circles in seventeenth century Dutch intellectual life to which his ideas were important which so quickly gave them European significance. ${ }^{2}$ It was the French journals published in Holland which did much to spread his fame; it was the personal contacts 
of his Remonstrant co-religionists which made him so particularly wellknown in England and thus established the association of modern natural law and Non-conformism which was to be reflected in the curricula of the dissenting academies for a very long time; and it was partly the circumstance that Scottish law-students from an early period went to Dutch universities for part of their training which laid the grounds for a fascination with Grotian ideas in Scotland which was to be maintained longer there than anywhere else, except Holland, Germany, and South Africa. ${ }^{3}$ But by whatever routes the ideas were channelled, the fact is that without Grotius we cannot well understand Hobbes and Selden, Locke and Cumberland, nor Stair's Institutes. ${ }^{4}$

It is true that Grotius' influence in England to some extent was part of the Arminian contribution to the upsurge of religious and ethical rationalism in the face of orthodox Calvinism and especially in the face of the Antinomian challenge of the 1640's. And it is true that this rationalism in its main outlines was traditional and carried with it old and well-known ideas of natural law - whether Nathaniel Culverwell's adaptation of Thomistic ideas, derived mostly from Suarez; ${ }^{5}$ or the neoplatonic synthesis of the Cambridge Platonists. ${ }^{6}$ But although this may have been the vehicle, it was exactly these traditional forms of natural law doctrine that the Grotian cargo was in the process of destabilizing and running off the rails. One climax of this was Hume's criticism of the ethical rationalism of Clarke, Wollaston, etc. (which D.D. Raphael quaintly calls 'the contemporary form of natural law theory ${ }^{\prime 7}$ ), as we shall see.

In short, Grotian ideas of natural law had established a foothold in the English-speaking world well before one can talk of a modern German natural law school. And the ground was thus prepared for the reception of this later German natural law (and its Swiss derivatives), both in Britain and in America, where a variety of continental natural law ideas, notably those of Pufendorf and later Burlamaqui and Vattel, ${ }^{8}$ were mingling with such 'higher law' concepts as could be extracted from the English legal tradition.9

Grotius' influence was also of basic importance in Germany. Much of the reception is to be found in commentaries on Grotius' De iure belli ac pacis, and scores of these works derive from university courses, for Grotian ideas played a major role in the academic confrontation with scholastic Aristotelianism. ${ }^{10}$ However, the catalyst for a great deal of the German development was the provocation received from Hobbes ${ }^{11}$ (somewhat later and to a much smaller extend Spinoza worked in the same direction). For Hobbes' idea of everyone's right to everything was seen as a most dangerous version of Grotius' subjective rights theory 
and it raised the question of how any form of moral, political, or legal obligation was possible. Amongst those who were roused by this problematic, to which we shall return below, was Samuel Pufendorf. It was Pufendorf's introduction of the Grotian and Hobbesian problems, and to a large extent also his answers to them, which started a tradition of natural law thinking which was to dominate in Germany for a century and a half. The point I want to emphasize here, however, is that Pufendorf, like Grotius, very quickly became a European phenomenon. This would probably have happened anyway, but its extraordinary extent and the speed with which it happened was due to Pufendorf's French translator and editor, Jean Barbeyrac, a French Hugenot and as such one of the army of talent which Louis XIV scattered over Europe through the revocation of the Edict of Nantes in 1685.12 Barbeyrac found refuge in Frederick I's Brandenburg and it was here that he first produced his great translations of Pufendorf, thereby also helping the process of integrating Brandenburg-Preussen into West European culture. Later he became professor of history and the law of nature in Lausanne, and he was in effect the founder of the Swiss school of natural law, whose other major names are Burlamaqui and Vattel. ${ }^{13}$ It was this group who made modern natural law a force in the French-speaking world at a time when nothing like it could be taught at French universities, and the most important factor in this was undoubtedly Barbeyrac's Pufendorf-translations (as well as his later translation of Grotius' De iure).

Barbeyrac's editions were elegant translations from the old to the new lingua franca, and we find in him many ideas about the importance of communicating matters philosophical, and especially moral, in the language used by those social groups which could play a civic role, rather than the language of the learned - ideas which had already been discussed slightly earlier by Christian Thomasius, the first philosopher to lecture in German; and ideas which would have been familiar to Francis Hutcheson, the first to lecture in English in the Scottish universities. But in order to serve their purpose to the full, Barbeyrac's editions had to be more than translations, and they are consequently equipped with prefaces and a wealth of notes which range from learned references to whole small essays discussing the original text; from quotations and translation from classical authors to points of contempory law. Barbeyrac here disclosed himself as in some measure what Hume wanted to be (and was), an ambassador from the republic of high learning to that of polite letters.

This Barbeyrac material was often included in translations of Pufendorf into other European languages, and in this way Barbeyrac's Pufendorf became such an influence in eighteenth century Europe. It was an 
extraordinary success-story - in fact I doubt if any other modern writer on moral philosophy was as widely read in Europe as a whole during the century between the English and the French revolutions. The main work, De iure naturae et gentium, was translated into Dutch, English, French, and German; while the shorter summary, De officio hominis et civis juxta legem naturalem, appeared in Danish, Dutch, English, French, Italian, Russian, Spanish and Swedish. A German scholar, Sieglinde Othmer, has counted 44 editions of the De iure during its first century of existence (and I am sure there must be more); of these 25 included the Barbeyrac material. Dr Othmer has found 79 editions of the De officio in its first 100 years, but this figure should at least be doubled; and again a large proportion of this staggering number of edtions contained Barbeyrac. ${ }^{14}$ Added to this, there is an enormous literature ranging from scores of compendia and elementa summing up university courses and based more or less directly on Pufendorf - and often Barbeyrac's Pufendorf - to literally hundreds of more independent treatises containing full systems of natural law which had to be related to Pufendorf, as to Grotius, whether favourably or critically.

The prevalence of natural law theory is also to be seen from the fact that so many of those who are generally understood to have superseded it nevertheless had to use it. In recent years this has become well known as far as a number of Scottish Enlightenment thinkers, and especially David Hume, are concerned - something we will return to in a moment. But we also know that Barbeyrac's translation of Pufendorf's De iure was a standard reference-work for Rousseau. ${ }^{15}$ Likewise Kant, despite his dislike of Grotius, Pufendorf, and their followers, lectured on the basis of a very traditional natural law text (by Gottfried Achenwall), and several of the problems he wanted to overcome were evidently posed for him by the natural lawyers. ${ }^{16}$ As a last example I may perhaps remind you that Hegel's Grundlinien der Philosophie des Rechts when it first appeared in 1821 also had a left-hand title-page stating a more general title, viz. Naturrecht und Staatswissenschaft im Umrisse. ${ }^{17}$ It is of course common to say that by this late period the original idea of natural law is largely forgotten or relegated to history, and that 'Naturrecht' is being used in so wide a meaning that it is virtually identical with 'philosophy of law'. But while some diffusion certainly took place, and while one should beware of relatively empty uses of 'Naturrecht', one should also take care not to see natural law doctrine as prematurely antiquated. I will below touch upon the late use of natural law in Scotland, but here I want first to point out that as far as Germany (and, incidentally, Denmark) is concerned Kant's critical philosophy is not at all the vale dictum of natural law theory, as is often thought. ${ }^{18}$ Through its criticism of traditional 
natural law ideas deriving from the schools of Pufendorf, Thomasius, Leibniz, Wolff and others, Kantianism itself becomes the foundation and inspiration for a whole set of natural law systems, thereby enhancing the force natural law still had in Germany at the end of the eighteenth century. In fact one near-contemporary survey (by Leopold August Warnkönig, 1839) lists an astonishing 108 major works on natural law between 1785 and 1831, most of them complete systems of natural law, and most of them more or less Kantian in character; and a modern Greman scholar, Diethelm Klippel, assures us that this count is very far from complete. ${ }^{19}$

Without entering into the intricate questions of the relationship between natural law theory and common law ideology, between natural law and the development of private law, especially the great European codifications, between natural law and the theory and practice of government, etc. etc. - without going into any of these matters I have tried very briefly to indicate the spread and longevity of the natural law tradition in modern Europe. Of course such considerations raise many more questions than they settle - questions of the coherence and continuity of the tradition, questions of its relationship to other modes of practical philosophy, etc. But the point I wish to make is that, irrespective of our judgement about these difficult matters, the fact remains that for a century and a half thinkers, great and small, throughout Northern and Western Europe and in America found the natural law doctrines stemming from Grotius and Pufendorf coherent enough to supply them with a continuous flow of ideas and problems. And this fact in itself warrants investigation.

II

While there were 'Machiavellian moments' during the seventeenth and eighteenth centuries, natural law was - as is fitting - perpetual. And one of the tasks looming large over future scholarship is to understand how the two conceptual worlds - the world of personal 'virtue' and 'political action' and the world of objective 'value' and institutional machinery - were related to each other. ${ }^{20}$ But before such a venture can have any hope of success, we need a much better understanding of the internal complexity of modern natural law theory. Some of the most significant complexity is due to the work of moral philosophers of the Scottish Enlightenment. Their work has commonly been dealt with in isolation from the natural law movement, most of them being regarded merely' as having a distant kinship with natural law, and at least one of 
them, Hume, being regarded as the great critic of natural law doctrine. These are clearly travesties of intellectual history; but, following the scholarship of recent years, and especially the great contribution of Duncan Forbes, ${ }^{21}$ I do not perceive them as likely to regain currency. We are beginning to have some idea of the place in natural law theory of Carmichael and Hutcheson, Turnbull and Kames, Hume and Smith;22 and while there is much more to be done on these thinkers, we have to add a number of others. Thus it is quite clear that Thomas Reid's unpublished lectures contain a significant statement of one kind of natural law theory, as well as a more explicit attempt to combine it with the humanist tradition in political thought than perhaps anywhere else in the eighteenth century. ${ }^{23}$ Some of the victims of James Beattie's wild eclecticism in his (published) lectures can only be identified via natural law. ${ }^{24}$ And the same applies, though at a much higher level of understanding, to Adam Ferguson's lectures, both as shown in the brief Institutes and in the full 2-volume course, the Principles of Moral and Political Science. ${ }^{25}$ Then there is John Millar, who despite all the other errands on which scholars have sent him out, remained faithful to the jurisprudence he had learnt from Adam Smith, as is shown sporadically in the Lectures on Government and the derivative published works, and especially in the Lectures on Civil Law, one part of which was simply a standard introduction to natural law theory. ${ }^{26}$ Millar lectured in this way until he died in 1801. As for Dugald Stewart, we know that he still regarded natural law theory, especially as derived from Grotius, as an obstacle to his philosophy of progress - called political economy - which was based on his Common Sense moral philosophy. ${ }^{27}$ Yet when we turn to Stewart's successor at Edinburgh, Thomas Brown, we find that his lectures contain a partial restatement of natural law ideas. ${ }^{28}$ Similarly, only a lack of understanding of the Scottish tradition in moral philosophy could make it entirely surprising that James Mackintosh, when he came to make his apostasy from the French Revolution, did so in the form of a series of lectures on the law of nature and nations. ${ }^{29}$ And so we could press on in time, as Duncan Forbes has done, by drawing attention to James Reddie's extraordinarily interesting Inquiries elementary and historical in the Science of Law from 1840;30 or we can change our focus to the great institutional writers, and especially Stair and Erskine, as Neil MacCormick and others have urged, in order to see how they absorb the ideas of the continental natural lawyers. ${ }^{31}$

But the fact that natural law theory persisted so late in Scotland multiplies the scholarly tasks significantly. One problem with which we have made virtually no progress is that the influence of the founders of modern natural law - which in itself is still poorly understood - 
becomes overlaid with the influence of later thinkers, not only Scottish, but also German and Swiss. Thus it is evident that e.g. the younger Cocceius, Heineccius, and Vattel all play some role in the lectures on jurisprudence of Smith and Reid, and I believe that Heineccius is of particular interest. His books were amongst the most wide-spread in Europe, and his most well-known natural law text was early translated by George Turnbull, Thomas Reid's teacher ${ }^{32}$ and, as Neil MacCormick has shown, Heineccius' theory of obligation was important for Erskine. ${ }^{33}$ Furthermore, Heineccius was also a well-known Romanist and this raises a general question which we must hope that legal historians will address themselves to, viz. the extent to which Civil law texts contained natural law material - we know the extent to which natural law texts carried Civil law concepts. The second large and wide open problem-area, which we encounter when we come to the very late eighteenth century, is the way in which Scottish moral philosophy came to influence natural law doctrine outside Scotland, and especially in Germany. ${ }^{34}$ This period in German philosophy is - not least from hindsight - so completely dominated by Kant that we tend to forget that his ideas were not only perennial wisdom, but also contributions to contemporary debates. His legal thought was thus, inter alia, also part of an ongoing debate about the relationship between law and morals, and amongst the many other contributors was Christian Garve, the most important of the muchmaligned Popularphilosophen. ${ }^{35}$ Garve was a reliable and prolific translator of English and Scottish moral philosophy, including the Wealth of Nations, and he was not - or at least not always - as mean a representative of this imported philosophy as he is charged with being; certainly his reading of Adam Smith's moral thought was more subtle than much subsequent scholarship. Similarly it should be pointed out that the distinctively liberal, anti-absolutist systems of natural law which were inspired by Kant's critical philosophy - sometimes taking it to lengths Kant himself would definitely not have gone - were influenced not only by Locke and Sidney, Montesquieu and Rousseau, but also by Hutcheson, Smith, and Ferguson. ${ }^{36}$

III

So far the questions I have asked far out-number the answers I have reported - and for very good reasons. Although we know enough about the position of the moral philosophy of the Scottish Enlightenment within modern natural law theory to see a rising edifice of questions, our answers are still concerned with the very basis of natural law. This is cer- 
tainly the case with the following attempt at interpretation which has to go right back to Grotius and Pufendorf and concern itself in turn with the tensions between theories of natural rights and theories of natural law and with the problems about the concept of obligation. Together these form a problematic which I will suggest is fertile for our understanding of the Scottish contribution; and if I am right in this, I hope to be offering you a supplement to $\mathrm{Mr}$ Forbes' more 'methodological' considerations which have given us such valuable insight into the empiricism and especially in the case of Hume - the secularism involved in the Scottish Enlightenment. ${ }^{37}$

Grotius' most important contribution to modern thought was his theory of rights, for although this had precursors, it was in his formulation that it gained currency. The central point is that Grotius in extension of, and undoubtedly inspired by, various scholastic thinkers, particularly the Spanish neo-Thomists, transformed the concept of ius as it is found in Roman law and in Aquinas. Instead of being something which an action or state of affairs, or a category of these, is when in accordance with law ius is by Grotius seen as something which a person has. The concept becomes 'subjectivised', centred on the person: it is a power which the person has, and it is as such also called a moral quality of the person. ${ }^{38}$

This transformation of the concept of ius is one of the cornerstones of modern individualism in political theory, for when ius is no longer an objective condition appointed by law, but something which individuals have, then the idea of human life as the exercise of competing individual rights is close to hand. And the extreme version of this was of course soon to be developed by Hobbes in his theory of the state of nature. But the thing that made Hobbes an outrage was the suggestion that the proper pursuit of our rights leads to anarchy and that the task of law consequently is to restrict our rights. By contrast Grotius and the mainstream of political theory saw conflict as a result of the improper pursuit of individual rights, and whether this arose out of malice or ignorance or both, the task of law was to make the proper exercise of rights effective for all by preventing the improper interference by some. Or in other words, in contrast to Hobbes Grotius operated with the idea that nature had made possible an ideal order in the moral world, and that the function of law was to maintain rather than create it. It was, however, a minimal order, as can be seen when we look closer at the content of ius. Ius considered as a power, is a power over other people, viz. the power to keep them off that which is 'one's own', one's suum. The realm of one's own is originally settled by nature as one's life, liberty, body, and everything in nature which is immediately required for one's 
maintenance; and it is subsequently extended conventionally into dominium, or property in things, and contractual relationships. ${ }^{39}$ This is the background to Grotius' second way of characterizing ius, viz. as that which is not unjust, meaning by this such actions as do not infringe upon the suum and dominium of others. ${ }^{40}$ (As has been pointed out, this leaves a conceptual gap betwen the two definitions of rights (as moral powers and as non-injurious actions), ${ }^{41}$ and I would suggest that this does not find a reasonably satisfactory closure until Adam Smith takes up the problem with his spectator theory, according to which rights as moral powers are functions of the interaction of the individual with others, when they as spectators judge that a person's actions are rightful because they are non-injurious. $)^{42}$

Whether it is set within the Hobbesian threat of natural disorder or within the Grotian promise of an ideal natural order, the idea that humanity from the hand of nature is engaged in an opend-ended, uncoordinated bargaining process in order to maintain its several rights, leads to the question of how a common life - morality and society - is possible. At the centre of Grotius' own solution to this problem of the possibility of society being established by individuals conceived as the owners of rights was an ingenious combination of his new idea of natural rights with a somewhat more traditional - and superficial - theory of natural law. When Grotius in the Prolegomena to the De iure belli ac pacis defines natural law in terms of man's socialitas, his social nature, this may at first sight remind one of Aristotle and St Thomas: Man is sociable because he is created to live in accordance with the law of nature to that effect. But this is explained and applied in a most un-Aristotelian manner, for the socialitas to which we are bound by the law of nature is for Grotius simply the respecting of each other's rights, subjectively conceived, so that the minimal order mentioned above, i.e. a minimum of social life is possible. And this brings him in a position where he could have dispensed entirely with natural law - as Karl Olivecrona has suggested..$^{43}$ For all that it tells us is that we should be what we are, viz. wielders of moral powers called rights, the content or scope of which is not settled by natural law, but by our situation in the world. Where Grotius' employment of the concept of natural law is nevertheless of some significance, is in disclosing the underlying assumption in the argument to which I have already drawn attention, viz. that the moral universe of individual rights in principle is well-ordered and without inherent conflict (though in practice, when people pursue their rights as they see them, conflict will of course arise from ignorance and immorality). For if prima facie conflicts between rights were not resolvable, it 
would mean that the law of nature allowed such conflict - or in other words, that God had not provided a morally right answer.

As seen by the next generation of natural lawyers and especially by the other great continental thinker of particular importance for us, Samuel Pufendorf, this was exactly the horrible possibility which Hobbes had taken up in his idea that from the hand of nature man is in a state of war. It was this that forced Pufendorf to investigate the subjective theory of rights and hence the whole question of the relationship between rights and the law of nature. For Pufendorf the ideas of Grotius and Hobbes simply presented a dilemma which can be explained as follows.

If the concept of subjective rights is moral in character, as Grotius clearly intends, then we must take it that it is morally right to exercise one's rights. But Pufendorf wants to know what lends this moral quality to such behaviour. Moral qualities cannot for him be said to be naturally inherent in human behaviour, for considered purely as natural events, human actions are simply cases of physical locomotion of the same kind that we find amongst the beasts, and it cannot be explained on this basis why some such events are denoucned as e.g. adultery, theft, murder, or incest only when done by humans. To think that moral qualities are inherent in human actions is for Pufendorf simply scholastic obscurantism of the sort which all the modern movements in philosophy had rejected. ${ }^{44}$ But what was the alternative? Well, the most thorough-going alternative was Hobbes' naturalism (later Pufendorf saw Spinoza as even more extreme in this respect). ${ }^{45}$ For according to Pufendorf, Hobbes did not see the exercise of rights as rightful action; the categories of right and wrong, just and unjust, simply did not apply to human behaviour as moral categories until covenants had established effective civic conditions for this. But this meant that morality was entirely conventional, a simple human invention. And not only that, it was an incoherent doctrine, for the covenants and agreements instituting civil society and human morality already presupposes morality if they are to impose an obligation. And this was the other - the Hobbesian horn of Pufendorf's dilemma.

His way out can be described as an attempt at a theological rescue operation on behalf of Hobbes' brand of naturalism. For Pufendorf clearly wants to preserve the idea that nature is a sui generis physical system describable purely in scientific terms, and for him this can only be done if values can somehow be seen as something independent which is superimposed upon the natural world. And in order to avoid Hobbes' problems this imposition has to be non-human in character. The world of values is therefore a separate creation by God, a structure of entia moralia laid down in addition to the creation of entia physica. ${ }^{46}$ This 
takes the form of law, and the reason why law creates a realm of value is that it is prescribed for creatures of free will who may or may not follow the law and thus do either right or wrong, good or bad. ${ }^{47}$ Right and wrong is thus made out of that which in itself is morally neutral when a rule is given to guide a free will. The human will can also give such guidance to itself when it enters into pacts and promises and thus undertakes obligations, ${ }^{48}$ and one human will can guide another by legislating for it. ${ }^{49}$ But these human activities are no more than extensions of the moral world instituted by the will of God in the law of nature; without the guidance of natural law, human volition and human action would be natural, non-moral phenomena like those we find amongst the rest of the animal creation. We may also make Pufendorf's point by saying that all man-made obligations are only morally binding in so far as they are prescribed by natural law as necessary means towards the goals set for human life by the same law.

Since the moral realm is introduced or imposed by the law of nature, the key-concept to match that of law is 'obligation': the law functions by imposing obligations upon us. ${ }^{50}$ It is thus only derivatively from the concept of obligation that we have the concept of 'right': right is what we can claim in accordance with natural law because this law has imposed an obligation on somebody to yield it. This relationship between the central concepts was pugently summed up by the Romanist and natural lawyer Johann Gottlieb Heineccius, who worked very much within the Pufendorfian tradition and whose books, as mentioned, for a long time were extremely widespread:

'es gibt kein Recht ohne Verpflichtung, keine Verpflichtung ohne Gesetz, kein Gesetz ohne Gesetzgeber. Gesetzt also, es gäbe keinen Gott, so gäbe es auch keinen Gesetzgeber, kein Gesetz und keine Verpflichtung, daher auch kein Recht.' ${ }^{51}$

It is true that Pufendorf occasionally also talks of rights in a Hobbesian sense as liberties left over from the restriction of natural law, but he makes it clear that this is simply an accommodation to an alternative linguistic usage ${ }^{52}$ though it is of course interesting that he finds such accommodation necessary at all. In general it is, however, perfectly clear that rights are derivative from obligations and thus from natural law. 
The tension between the Grotian and the Pufendorfian views of the relationship between natural laws and natural rights is the first great problem I wanted to extract from the continental natural law tradition of the seventeenth century, because it plays an important role in our understanding of the moral philosophy of the Scottish Enlightenment. But before we can use it for this purpose, we have to connect it with another basic problem in the natural law doctrines from which the Scots started, viz. the question of the basis for natural law..$^{53}$

We here meet a group of ideas which are very wide-ranging and whose interpretation is highly controversial. What is clear is that natural law theories during the seventeenth and eighteenth centuries lost more and more of their theological appearance, and as they increasingly became theories of state-law, they instead gained in purely juristic technicality. ${ }^{54}$ But as soon as we try to pinpoint this development in particular thinkers, we are in difficulties, running a constant danger of 'premature secularization' ${ }^{\prime 55}$ in our interpretation. And this is where the controversies rage. To most of the modern scholars who write outside the Catholic natural law tradition it seems obvious that the secularization begins decisively with Grotius himself. On the other hand, to scholars within the Catholic tradition it seems equally clear that Grotius' alleged secularism amounts to little more than a restatement of a position already worked out within the Church by a number of late scholastic thinkers. ${ }^{56}$ And to everyone it is clear that all the great post-Grotian natural jurists within Protestantism - Locke, Cumberland, Cudworth, Clarke, Pufendorf, Leibniz, Thomasius, Wolff - as well as the lesser ones - the two Cocceii, Heineccius, the Swiss Protestants (Barbeyrac, Burlemaqui, Vattel et al.), and some of the Scottish thinkers we will look at later - that each of these in one way or another work with some sort of Christian foundation. In this situation it may be tempting to close the books with the verdict that the secularization of natural law theory amounts to nothing but a relative neglect of theology in favour of juristic technicality induced by the decreasing controversiality of the problems as religious strife calmed down in Europe. But while this is quite true, it is a poor substitute for an explanation, and while I cannot promise to provide a full explanation, I can at least try to open up the problem for further discussion.

I have - in common with so many before me - talked vaguely of the bais or foundation of natural law. As a first step we need to clarify this by drawing some distinctions - even if some of these are anachronistic, arising as they do from post-Kantian ways of thinking, for it is after all the lead-up to these ways that we are studying. Let us separate the 
following four: Firstly, the question of the ground of existence of natural law; secondly, the question of the basis for or source of our knowledge of natural law; thirdly, the question of the ground of our obligation to natural law; and fourthly, - though I will hardly touch upon this here - the question of our motivation to follow natural law.

As to the first question concerning the ground of existence of natural law, there is never any doubt in any of the modern natural lawyers until we come to Hume that in creating the world God created the law by which it is natural for man to live. But they held this basic opinion on religious grounds which ranged from the orthodox Lutheran and Calvinistic to more or less philosophically founded deism. And this indicates very well that the question of the ground of existence of natural law is not a very interesting one in itself, and that any shift in the foundations of natural law must arise in one or more of the other areas. In fact I think that the key questions are concerned with the knowledge and the obligation of natural law and not least with the connection between the two. The modern debate about these problems had, paradoxically, its starting-point in a piece of traditional scholastic wisdom in Grotius. Like natural lawyers before, and generally also after him, Grotius never held any doubts about God's authorship of nature and thus of man and the law by which he should live. And yet in a completely hypothetical manner he made the point that if natural law was inherent in the nature of things as they de facto are, and if our natural understanding of our life is sufficient to see the obligations which this imposes upon us, then this would still be the case 'even if we should concede that which cannot be conceded without the utmost wickedness, that there is no God, or that the affairs of men are of no concern to him. ${ }^{57}$ This is the famous etiamsi daremus passage upon which the picture of Grotius as the great secularizer has often been built, but it has time and again been pointed out that he is merely following in the footsteps of a scholastic tradition which goes back at least to the mid-fourteenth century, and especially that he is doing little more than re-phrasing what his older contemporaries in the Spanish neo-Thomist school had said. ${ }^{58}$ Nevertheless the appearance of this idea in Grotius makes it dramatically different and problematic when compared with the scholastic, especially Thomistic, setting. In Thomistic theory a natural, non-theological understanding of the law of nature could lead to an obligation to this law because of the insistence on a common human good which was the undeniable object of natural human reason in practical matters - a theory which has recently been reworked with particular ingenuity by John Finnis. ${ }^{59}$ But this avenue was not very readily available to Grotius because of his adoption of a subjective rights theory the tendency of which was to dilute the con- 
cept of the common good to very little indeed, viz. the maintenance of mere compatibility in the pursuit of individual rights claims. Grotius himself did not, I think, appreciate, nor did he find a consistent answer to the problem he had thus thrown open by introducing the traditional thought of the etiamsi daremus passage into a subjective rights theory. But it was one of the most important tasks he left for posterity, and especially for David Hume, to show how such a meagre idea of the common good as that implied by the theory of rights could be the ground of obligation to rules of justice.

The Scottish debate about these matters was, however, further complicated by the influence of Pufendorf's line of argument. We have already seen that the central point in Pufendorf is his rejection of what he takes to be Grotius' realism in moral matters and his insistence upon a strongly voluntarist theory in which the primary concepts are law and obligation. But how does Pufendorf account for men's obligation to natural law itself? First of all he distinguishes between our knowledge of the content of natural law on the one hand, and our obligation to natural law on the other..$^{60}$ We come to know the precepts of natural law simply by contemplating human nature and its situation in this world. But this does not make these precepts into an obligatory law for us, for 'all law supposes a superior power', ${ }^{61}$ and the only such power antecedent to human institutions is God. So we must suppose that the law of nature is God's command. Fortunately the very fact that the precepts of natural law are so obviously designed to help men out of the unfortunate situation they would otherwise be in and thus to help them realize their true human potential is not lost on even the meanest intelligence, and unless men are so perverted as to be virtually sub-human, they spontaneously give the design award to the deity.

Pufendorf's idea of obligation to natural law is thus very much dependent upon a theory of natural theology, but it was exactly because of the insufficiency of this theory that he was most strongly attacked. These criticisms were developed in remarkably similar fashion, though independently, by Leibniz and by the earliest of the Scottish moral philosophers with whom we will be concerned here, viz. the Glasgow regent and later professor Gershom Carmichael. At the heart of the difficulties was the impossibility of maintaing a consistent voluntarism of Pufendorf's kind. Since he insisted that natural law springs from God's will, this will must be authoritative for one of two reasons: either because it is backed by a superior power, or because it has some moral force. Now, if God is authoritative because he can know all and punish all, then the resulting obligation is not moral at all, but merely prudential in character, and Pufendorf has thus hardly advanced beyond Hobbes, 
as he obviously wanted to do. Furthermore, if such prudential obligation were to be effective, it would seem to require that we have a natural (as opposed to revealed) knowledge of the ultimate sanction of the law of nature, viz. an insight into what awaits us in the hereafter. But in his attempt to separate natural law from revealed religion Pufendorf specifically denies that we have such natural knowledge, and insists that this is a matter of revelation. ${ }^{62}$ If alternatively God's authority is moral in character, then we must have moral criteria or principles by means of which we recognize the goodness of God's will and which hence cannot simply be a matter of God's will. Or as Leibniz nicely sums it up: 'if the source of law is the will of a superior and, inversely, a justifying cause of law is necessary in order to have a superior, a circle is created, than which none was ever more manifest. ${ }^{63}$ Furthermore, if the obligation to natural law springs from an insight into its goodness, then it is not just an obligation in foro externo, an obligation to follow the law in overt action, but also an obligation in foro interno, in conscience. And yet Pufendorf is emphatic that if natural law is to be separated from theology, then it can only be concerned with extrinsic obligation, whereas intrinsic obligation must be considered a theological matter. ${ }^{64}$ Pufendorf's difficulties over this distinction between extrinsic and intrinsic obligation - which became well-known in institutionalist writers such as John Erskine, who took it from Heineccius ${ }^{65}$ - may also be shown in the following way. On the one hand he defines good actions as actions in accordance with law (ultimately of course natural law); ${ }^{66}$ but he also says that in order to be really good an action has to have the law as its cause ${ }^{67}$ - in later parlance, to be for the sake of the law or out of respect for the law.

Summing up, we can see that at the end of the seventeenth century the natural law tradition presented a set of deep-seated and very difficult problems which were of the first importance to its successors in the new century. On the one hand we are presented with a subjective rights theory which, if taken to extremes as it was by Hobbes, questioned the possibility of an objective moral order and thus the meaningfulness of the concept of natural law and of obligation to a natural, objective standard of moral behaviour. On the other hand we find a concerted effort to establish a voluntaristic alternative riddled by a number of difficulties, central amongst which is its inability to account for the obligation to natural law. These difficulties in the very foundation for a theory of natural law are of course reflected dramatically in the accompanying ideas of the human extensions of natural law, and especially in the theory of property and the theory of civil government. But these are matters 
which we will have to leave aside for another occasion, although some of them will be sporadically touched upon in the sequel.

It is interesting to note that both in Germany and in Scotland the first reaction against Pufendorf consisted partly in a renovation of the Christian idea of love - agape, or more immediately, caritas ordinata - and partly in a sentimentalist theory of moral judgement. In Germany the prime mover was Christian Thomasius; in Scotland it was a stepwise progression from Carmichael to Hutcheson. It is the latter who concern us here. The idea of an - in both senses of the word - 'ordered' love of others as the essence of human morality was undoubtedly reflected in both Grotius' and in Pufendorf's concepts of socialitas, ${ }^{68}$ but in the absence of any powerful theory of the human good to be created by love, it could only be a very pale reflection. This is where Carmichael steps in, and he does so on lines very similar to the Christian proto-utilitarianism of Richard Cumberland. ${ }^{69}$ God is love and he has created man in his image to love him both directly and, more importantly here, indirectly through love of and care for God's creation. ${ }^{70}$ The object of such love is the happiness of all rational beings, the common good, and the precept that such good is to be pursued through our love - or 'benevolence' - is the essence of the law of nature. ${ }^{71}$ This law, of course, has its ground of existence in God in as much as it is a part of, or rather a consequence of, God's creation. But is has its ground of cognition in our natural understanding of the design of the world and of man's position in it.72 And it has its ground of obligation in the common good which for human reason is an undeniable good. ${ }^{73}$

In view of this, it is hardly surprising that Carmichael has a few words of praise for 'scholastic ethics' 74 - brave words, given the time and place. But we must beware that this, and his rejection of Pufendorf's voluntarism, does not lead us to overlook the really novel aspects of his theory, of which the most important is that he finds room for a strong theory of rights. Carmichael's argument here is as ingenious as it is simple. ${ }^{75}$ Although he does not commit himself to the simple view that the common good is merely an aggregate of individuals' goods, he obviously thought that generally the common good is augmented by the addition of individual goods (or 'utilities'). Each individual does have an obligation under natural law to promote individual utility both in himself and others. This is an interesting meeting-point of old and new in moral thought, for on the one hand we see that Carmichael subscribes to the 
traditional tripartite division of human duties into duties of God, to ourselves and to others; and on the other hand it is quite clear that he has accepted a crucial feature in later utilitarianism, viz. that the maximization of utility as a basic precept for moral action includes oneself on a par with others. However, the thing which particularly interests us here is the derivation of the concept of rights, which Carmichael undertakes in the following manner. ${ }^{76}$ Since the individual pursuit of happiness is always prone to give rise to conflict, and since each person is generally the best servant of his own interests the duty towards others has the general form of a duty to be social, which means a duty to accommodate one's own interests to those of others and a duty to leave others to serve their own interests as far as possible. Or in other words, our obligation to others is to respect their rights to pursue their own interests.

Superficially this line of reasoning may seem to be the same as that of Pufendorf - the law of nature imposes obligations on us from which we drive corresponding rights in others. But the crucial difference is Carmichael's concept of the common good as an objective measure: we have rights not just because others have obligations towards us, but exactly because it contributes to the common good that we each have rights to pursue our interests. It is this which makes rights into independent or objective properties, so to speak; something which we each have and can hold against others to show what obligations they have towards us. While rights and obligations for Pufendorf are perfectly matched for the simple reason that the imposition of obligations gives rise to rights in others, rights and obligations are for Carmichael in perfect correspondence - ideally speaking, of course - because they are both derived from and have reference to the objective measure of the common good which is pointed out by the law of nature. It is this which makes his theory into such an interesting balance between the notion of subjective rights and a still meaningful concept of natural law. And, not least, it is this which makes his theory of such seminal importance for the further development of moral philosophical debate in eighteenth century Scotland.

The moral philosophical, or jurisprudential, concept of the common good is in my opinion of very central significance to our understanding of the whole of the practical philosophy of the Scottish Enlightenment. But it is also a concept which it is peculiarly difficult to disentangle from its usual context. The greatest difficulty is perhaps to keep it separate from a political concept of the common good, or the public interest as it is often called. The political concept of the common good is normally understood by contrast with the sectional interests of particular groups which have to be curbed and balanced in order for the long-term interest 
of the society as a whole to be served. This is particularly well-known from Hume and Smith, but it is to be found in some form in most of the Enlightenment thinkers - if in no other way, then in connection with considerations of the balance within a mixed constitution. But this concept of the common good also has to be seen in relationship to the moral philosophical concept of the common good, for the latter is the guiding ideal for the exercise of political power, and it is therefore that which ultimately is in the public interest, that for the sake of which sectional interests have to reach compromise. But by the same token it is also that which may have some of its parts set to one side in order for political compromise to be reached. In short, the two concepts of the common good are related as the politically feasible to the jurisprudentially ideal, and the scale between the two provides an initial and primitive thermometer with which to check the political temperature of a thinker whether it approaches feverish utopianism or cool realism. It is, however, a crude instrument, for a very great deal depends upon the concept of the moral good which a particular thinker accepts, and it is this which is of particular interest to us here.

As I see it, a clear dividing line runs through the moral philosophy of the Scottish Enlightenment over this issue. To the one side of it we have those - the large majority - for whom the common good which is of jurisprudential relevance is of very wide extent, viz. more or less identical with moral goodness as a whole. On the other side of the line we have a few - and especially Hume and Smith - for whom only part of moral goodness falls within the province of jurisprudence, so that they operate with a much narrower and in fact more formal concept of the common good which amounts to little more than the maximum compatibility of individual interests. We may also express this deliberately simplified division by saying that for Hume and Smith only the negative virtue of justice or - in rights-language - only perfect rights fell within jurisprudence whereas for most of the other Scottish moral philosophers of the eighteenth century both the rest of the virtues and the imperfect rights had some jurisprudential standing, though it is an extremely difficult question to say exactly which. This will be the subject of the final section of my paper, but before proceeding to this I would like to make a few general remarks about the metaphysical and epistemological issues raised by the new Scottish departure in moral philosophy. Normally these are discussed with reference to the Scots' reading of such moralists as Shaftesbury, Butler, and the ethical rationalists, and I do not intend to contest this line of interpretation, but simply to supplement it with some reflections springing out of the present context.

The division over the concept of the jurisprudentially relevant com- 
mon good which I have indicated, is connected with a certain division in metaphysics and epistemology. This is, however, anything but a simple and clear-cut issue, because the large group of thinkers who subscribe to the broad concept of the common good are so very different amongst themselves. For in this group I include Carmichael, Hutcheson, Turnbull, Kames, Ferguson, Reid, Beattie, Oswald, and Stewart. And they thus range from Reid's realism and cognitivism to Hutcheson's difficult and in places obscure position which Tom Campbell recently has characterized as an attempt 'to find a via media between naive realism according to which aesthetic and moral qualities exist in objects independently of the involvement of any observer, and non-cognitivism according to which moral judgement reduces to the experience or expression of feelings. ${ }^{\prime 77}$ The common denominator which I nevertheless find it useful to draw attention to in this heterogeneous group is the even more basic idea of an objective moral order, the elements of which are open to apprehension by some human faculty. The order may be conceived either in terms of qualities in actions, or in terms of the coordination between certain types of action and our reactions to them, or in terms of both; and its mode of apprehension may be seen either as a matter of rational judgement or as some sort of 'sensing'. But on either view it is not an order which is created by human activity. On the contrary, it is an order upon which men draw and which thus lends order and structure to human activity. In this respect the view of Hume and Smith is very different. For them the realm of values is imposed upon the natural world, as it was for Pufendorf, but it is not due to divine agency, nor is it deliberate in character. It is rather due to the social interaction of individuals, and its core is the ideal impartial standpoint which can mediate the natural, emotionally based actions and reactions of individuals. The realm of values is thus for Hume and Smith not an objectively given order, but an order which is being formed and reformed or in other words, a constant process of objectification. In this process some types of outcomes, some values, may be fairly universal, while others will be subject to significant change, or 'progress' - that is a matter for empirical investigation in the 'experimental' science of morals.

\section{VI}

These reflections concerning the nature of the common good which provides the ground of obligation to natural law, or which makes it a virtue to follow the rules of justice, or which justifies respect for rights (whichever language is preferred) - these reflections are of basic impor- 
tance for an understanding of the content of 'natural law', or 'justice', or 'rights'. For a wide concept of the common good tends to be reflected in a comprehensive natural law, in an unwillingness to distinguish sharply between justice and the other virtues, and especially in difficulties in separating perfect and imperfect rights. These were standard issues in both German and Scottish natural law theory throughout the eighteenth century. But while they have a fairly direct ancestry in Aristotle's wellknown distinction between universal and particular justice, ${ }^{78}$ it was again Grotius' handling of this distinction which was to determine the modern debate. ${ }^{79}$ Firstly, Grotius translated the distinction into rightslanguage, saying that the sort of right protected by what Aristotle called particular justice was a perfect right or a 'faculty', and these rights were divided into three well-known areas, powers (over oneself, i.e. liberty, and power over others in non-political relationships), property rights, and contractual rights; while the 'rights' protected by Aristotle's universal justice were imperfect and mere 'aptitudes', i.e. such as is 'fitting' or 'suitable', ${ }^{80}$ Furthermore, only the former kind of justice 'is entitled to the name of justice properly or strictly so called', for only the rights pertaining to it are, as indicated by the label 'perfect', really rights. And by this he means that they are the only legally necessary rights, i.e. the only rights which are necessary for the every existence of society amongst men:

This maintenance of the social order, which we have roughly sketched, and which is consonant with human intelligence, is the source of law properly so called. To this sphere of law belong the abstaining from that which is another's, the restoration to another of anything of his which we may have, together with any gain which we may have received from it; the obligation to fulfil promises, the making good of a loss incurred through our fault, and the inflicting of penalties upon men according to their deserts. ${ }^{\prime} 1$

From the point of view of justice no more than this is due to anyone, ${ }^{82}$ and if more is to be given it must either be done freely out of more positive moral considerations than those of justice, or it must be imposed by divine or human positive laws justified by such considerations. What we see is that Grotius' theory of rights sharpens the division between justice and other other virtues, and when he also excludes the latter from natural law, an important step is clearly taken towards a separation of law and morals. It is, however, far too simple to declare, as Alf Ross has done ${ }^{83}$ that Grotius and the modern natural law school secured this separation for jurisprudence. As already indicated, Grotius himself saw important moral roles for both divine and human positive law, but he 
did not explain the exact relationship of these areas of law to the straightforward laws of justice which implement natural law. And for all subsequent natural law theory this was one of the most troublesome and important problems, as can be seen from the following case studies.

As a first instance, Samuel Pufendorf protested against Grotius' narrowing down of the Aristotelian concept of justice. He admitted that there was a distinction between universal and particular justice and that it referred to the distinction between imperfect and perfect rights. He further agreed that only the latter were subject to rigorous legal enforcement. But he maintained in effect that the distinction was merely heuristic, viz. based on what was practically necessary for the maintenance of human society - not on any moral difference between the two kinds of rights, for all rights were equally appointed by natural law:

Now that some things should be ... due to us Perfectly, and others Imperfectly, the Reason amongst those who live in a State of natural Liberty is, the great Diversity of Precepts in Nature's Laws, of which some conduce to the very Being, others only to the well-being of Society: And therefore; since there's less Necessity of performing these latter than the former, Reason shews that the former may be requir'd and executed by more severe Courses and Means; whereas in regard to the latter, it is meer Folly to apply a remedy more grievous than the Disease ... In Civil Communities this Difference ariseth from the particular Laws and Constitutions allowing or disallowing an Action in such and such Cases. Tho' most Commonwealths do in these Points follow the Tract of the Law of Nature; except where they have some particular Reasons advising the contrary. When then, we exhibit to another either Actions or Things due to him only by Imperfect Rights, or when we exercise towards another Actions not coming under the Head of strict Commerce, we are said to have observ'd, General or Universal Justice .... But when we perform towards another Actions falling under Commerce, or such as transfer any thing on another, to which he had Perfect Right, this is call'd Particular Justice. ${ }^{84}$

The important thing here is that perfect and imperfect rights have an equal moral foundation in natural law, for this implies not only that in some situations the latter carry a moral obligation which overrides the former - e.g. one has an obligation of charity to give of one's property or an obligation of benevolence to give of one's free time to those in need of either - but it also means that it is on occasion morally justified for the ruler to protect imperfect rights legally. This is spelled out later: 
'And tho' in regard to bare Natural Right, for a Man to relieve another in Extremity with his Goods, for which he himself hath not so much Occasion, be a Duty obliging only Imperfectly, and not in the manner of a Debt, since it arises wholly from the Vertue of Humanity; yet there seems to be no Reason why by the additional Force of a Civil Ordinance, it may not be turn'd into a strict and perfect Obligation.' 85

Between the theories of Grotius and Pufendorf there is thus a tension which was influential for the eighteenth century, and in Britain it was accentuated further by the differences between Richard Cumberland and John Locke, a topic which has recently been explained by James Tully with particular reference to property: 'Cumberland completely reverses the roles of expletive [particular or negative] justice and distributive [universal] justice. The government's duty is to distribute property in such a way that the common good can be realised, and then protect it. Private property is seen as the conventional means of individuating man's natural right to his due' ${ }^{86}$ On the other hand Locke is hailed in the eighteenth century as the great protagonist of limiting government to the task of protecting individual rights, with the clear implication that this task is both clearly defined and on a firm moral footing because the rights in question have these qualities. This of course lent further urgency to the dispute between Grotius and Pufendorf about the extent of the concept of rights: were imperfect rights conceptually clear enough and morally well enough founded to be within the orbit of government without endangering the limitation of government? ${ }^{87}$

Part of the problem had been met head-on by Christian Thomasius who explicitly repudiated Pufendorf and returned to Grotius' distinction between perfect and imperfect rights and developed it into a much clearer distinction between law and morality on the basis of a distinction between what can legitimately be enforced and what cannot. But in Scotland the distinction between justice and the rest of morality, and hence the separation of law and morals, was based on a more original and important moral philosophy than that of Thomasius, viz. the secularized theory of David Hume and Adam Smith. In Scotland the whole problem strikes much deeper than anywhere else.

Hume and Smith follow closely in the footsteps of Grotius when they distinguish sharply between justice and all the other virtues, and when they characterize justice as a mere negative virtue concerned with what not to do, whereas the other virtues are positive guides to action. ${ }^{88}$ Smith in particular develops an elaborate theory of this which centres on two ideas, firstly the principle that injury to persons - which is the object of the virtue of justice in the negative sense - is much more universal in 
meaning than the positive goods which are the objects of the other virtues; and secondly the principle that the avoidance of evil has moral priority over the obtaining of good. The net result is therefore that justice is the most fundamental virtue necessary to ensure the existence of any human society; and because of the properties just mentioned, there will always be a spontaneous tendency to formulate justice in sharp and clear rules, which will by and by achieve the character of law.

These are, then, what Smith called 'laws of justice', and like Hume he saw it as the over-riding duty of civil government (apart from defence) to maintain these laws. It was exactly because he saw this task historically as a most difficult one that his plea for limited government was also a plea for strong government. But it is important to realize that Smith clearly envisaged other tasks for government than the maintenance of a system of justice. There was also a requirement for a variety of so-called laws of police' which should pursue some positive good for the society, ranging from public works to public education. However, these positive tasks of government were secondary to the maintenance of the laws of justice; they were subject to the test of justice, and they were generally conceived as direct or indirect supports for the functioning of the system of strict negative justice.

It seems obvious that these developments of Grotius' idea of justice must be considered amongst his most important legacies. And this can perhaps be put into further perspective by glancing at a few of the other eighteenth century Scottish thinkers who were well aware of the preceding European debate about the ideal of justice which should be directive for political power. We find the problem debated by all the Scottish philosophers - by Gershom Carmichael, George Turnbull, Thomas Reid, Francis Hutcheson, Lord Kames, and Adam Ferguson. Let us here just look at Hutcheson and Ferguson.

Hutcheson builds directly on the kind of rights-theory which we found in Carmichael, but he develops its philosophical foundation into a much clearer utilitarianism, defining a right in the following way: 'a man hath a right to do, possess, or demand any thing, 'when his acting, possessing, or obtaining from another in these circumstances tends to the good of society, or to the interest of the individual consistently with the rights of others and the general good of society, and obstructing him would have the contrary tendency. ${ }^{\prime 89}$ This immediately gives Hutcheson a ground for the traditional distinction between perfect and imperfect rights; those which are so useful to general happiness that human society cannot exist without them are perfect, those of lesser utility are imperfect. But he is quite clear that this is by no means a sharp division: 
'the boundaries between perfect and imperfect rights are not always easily seen. There is a sort of scale or gradual ascent, through several almost insensible steps, from the lowest and weakest claims of humanity to those of higher and more sacred obligation, till we arrive at some imperfect rights so strong that they can scarce be distinguished from the perfect. ${ }^{\prime 90}$

Not only this, but Hutcheson also draws the conclusion with great clarity, that since the moral ground for rights is the natural law about the maximization of happiness, all individual rights, including perfect rights, are defeasible by actions of greater utility than their protection in particular cases and types of cases: 'no private right can hold against the general interest of all. For a regard to the most extensive advantage of the whole system ought to controll and limit all the rights of individuals or of particular societies. ${ }^{91}$ In this connection it should also be remembered that Hutcheson's utilitarianism is part of the providential order of the universe and hence we can be sure that morally right actions will never be in conflict with each other, ultimately at least; thus he emphatically maintains that perfect and imperfect rights, when properly conceived, are never really in conflict. ${ }^{92}$

While the law of civil society is not restricted to the protection of a system of perfect rights, this is nevertheless also for Hutcheson its main task. But added to this we get in him a very clear concept of positive virtue as a matter of policy, as opposed to law: the strong encouragement to moral and religious education and to thrift as well as political and military exertion, partly by creating suitable institutions, partly by setting an example, and only in greatest necessity by means of legal enforcement. ${ }^{93}$ And this is considered to be a duty for government which is morally on a par with the enforcement of justice.

In Ferguson we also find that the primary object of law is that which may justifiably be defended by force, and that this is a system of perfect, exclusive rights which we exercise in a world which is given to us in negative community from the hand of God or nature. ${ }^{94}$ Further, we find that there is a body of public law, the justification of or rationale for which is - much like in Smith - the defence and effectivity of private law. ${ }^{95}$ In contrast to this, morality - i.e. the exercise of the four cardinal virtues - is outside the compulsion of the law and is only subject to 'encouragement', which it finds in the verdicts of the individual's conscience, of religion, and of public repute. And when law and morality are thus distinguished, their 'sanctions are supposed to be distinguishable also, under titles of perfect and imperfect obligation. ${ }^{\prime 96}$ But although this may be commonly 'supposed', it is nevertheless dangerously misleading to human morality, for 'it ought not to be implied in any words we 
employ, that a rule, merely because it may be enforced, is in any degree more binding than the consideration of what is in itself an article of wisdom, as constituent of good to mankind.' 97

So despite all the emphasis on the 'necessity' and consequent enforceability of law, in contrast to morality, and notwithstanding the implication that this necessity has a moral ground in the further necessity of society as a means to the realization of human morality, we nevertheless have it stated as a general principle that law has no greater moral obligation than the moral virtues as such. And this principle is quite basic to an understanding of Ferguson. It is true that we do not find in him the sort of clear-headed utilitarian argument which we found in Hutcheson, according to which 'virtue' on occasions might overrule 'mere justice' within the law itself. ${ }^{98}$ But we do find him pursuing with even greater vigour than Hutcheson the complementary line of argument, that 'virtue' should be a matter of policy. Thus the central mission of his first and most influential work, the Essay on the History of Civil Society, was that the legal protection of individual rights to pursue our interests, which it was the glory of modern commercial society to have achieved, was not enough, morally speaking. The very security in this pursuit might well be the bane of civilization, unless the 'spirit', the moral stature of the individual was attended to.

With Ferguson's fervent attempt to have it both ways the tension we have been tracing in the concept of justice, or between 'negative justice' and positive 'virtue', reaches a crescendo. Hutcheson could have resolved the issue by means of his utilitarianism, but it would have required him to abandon the concept of rights (except legal rights in positive law, of course). After him we have to wait for Thomas Reid to find a philosophically coherent answer to the Grotian line taken by Hume and Smith. But what was the moral philosophical question which set Hume and Smith apart from the rest of their Scottish contemporaries? We might approach this question by pointing out that for the former two the freedom of individual pursuit had achieved a morally justified primacy in political contexts (though not necessarily in other contexts), which overruled other moral claims, whereas for the latter there was a tension between this 'formal' ideal of freedom and the ideal of another sort of freedom, viz. freedom from moral delusion and hence the achievement of a particular virtue which was universally objective for mankind. So behind this issue lies exactly the question of the objectivity of morals, or the question of the existence of a common moral good which is more than the mere co-existence of individual rights. Such a concept of the common good was the price Carmichael paid for his theory of rights, as we have seen. But once it was questioned, the road was opened for the 
well-known Scottish enquiries into the extent to which morals were subject to historical change: was there a universally valid ideal of the moral virtues as in the Common Sense philosophy, or was such universality confined to some minimal, formal aspect of moral reasoning concerning justice without which human society could not exist, as in Hume and Smith? Thus it is the continuation of the debate about Grotius' theory of justice in Scotland which leads directly to the troublesome question of the historicity of morality, law, and civil government. I can offer you no better example of the longevity and coherence of the debate within the modern school of natural law.

\section{KNUD HAAKONSSEN}

Australian National University

\section{Notes}

1 Cf. K. Haakonssen, 'Hugo Grotius and the History of Political Thought', Political Theory, 13 (1985), pp. 239-65.

2 Cf. R.L. Collie, Light and Enlightenment: A Study of the Cambridge Platonists and the Dutch Armenians (Cambridge, 1957).

3 Cf. T.B. Smith, 'Scots Law and Roman-Dutch Law, A Shared Tradition', in his Studies Critical and Comparative (Edinburgh, 1962), pp. 46-61; and his 'A Meditation on Scottish Universities and the Civil Law', ibid, pp. 62-71. Peter Stein, 'Legal thought in Eighteenth Century Scotland', Juridical Review, 1957, pp. 1-20; 'The General Notions of Contract and Property in Eighteenth Century Scottish Thought', Juridical Review, 1963, pp. 1-13; 'Influence of Roman Law on the Law of Scotland', Juridical Review, 1963, pp. 205-245; 'Law and Society in Eighteenth-Century Scottish Thought', in N.T. Phillipson and Rosalind Mitchison, eds, Scotland in the Age of Improvement (Edinburgh, 1970), pp. 148-68. D.N. MacCormick, 'Law and Enlightenment', in R.H. Campbell and A.S. Skinner, eds, The Origins and Nature of the Scottish Enlightenment (Edinburgh, 1982), pp. 150-66. And R. Feenstra and C.J.D. Waal, Seventeenth-Century Leyden Law Professors and Their Influence on the Development of the Civil Law. A Study of Bronchorst, Vinnius, and Voet, Koninklijke Nederlandse Akademie van Wetenschappen. Afd. Letterkunde, Nieuwe Reeks, Deel 90. (Amsterdam and Oxford, 1975), pp. 81-88.

4 Cf. Richard Tuck, Natural Rights Theories (Cambridge, 1979), chaps. 3-6. James Tully, A Discourse on Property. John Locke and His Adversaries, (Cambridge, 1980), esp. pp. 92-100.

Karl Olivecrona, 'Appropriation in the State of Nature', Journal of the History of Ideas, 35 (1974), pp. 211-30; 'Die zwei Schichten im naturrechtlichen Denken', Archiv für Rechts und Sozialphilosophie, 83 (1977), pp. 79-103. 
'Locke's Theory of Appropriation', Philosophical Quarterly, 24 (1974), pp. 220-34.

D.M. Walker, Introduction to James, Viscount Stair; The Institutions of the Law of Scotland, ed. D.M. Walker (Edinburgh, 1981). Geoffrey MacCormack, 'Grotius and Stair on Promises', American Journal of Jurisprudence, 22 (1977), pp. 160-67.

5 See Nathaniel Culverwell, An Elegant and Learned Discourse of the Light of Nature (1652), ed. by R.A. Greene and H. MacCallum (Toronto, 1971), esp. chapters IV-VII. Before him Richard Hooker had, of course, developed a Thomistic line of argument which was to become important later in the seventeenth century.

6 C.A. Patrides provides a guide both in his Introduction and his selection and annotation of texts: C.A. Patridges, ed. The Cambridge Platonists (London, 1969). Cf. also R. Hoopes, Right Reason in the English Renaissance (Cambridge, Mass., 1962).

7 D.D. Raphael, 'Hume's Critique of Ethical Rationalism', in W.B. Todd, ed., Hume and the Enlightenment (Edinburgh and Austin, 1974), p. 15 (my emphasis). Duncan Forbes is, of course, quite right in criticising a too close identification of natural law theory and ethical rationalism and in insisting on the empirical aspects of the former, but in order to sort out this problem we would have to go much further into the great diversity of natural law doctrines in the time immediately prior to Hume than we can do here. See Forbes, 'Hume's Science of Politics', in G.P. Morice, ed. David Hume, Bicentenary Papers (Edinburgh, 1977), p. 45.

8 See A. de Lapradelle, Introduction to E. de Vattel, Le droit des gens 3 vols. (Washington, 1916), vol. I, pp. xxvii-xlii. F.S. Ruddy, 'The Acceptance of Vattel', Grotian Society Papers, 1972, Studies in the History of the Law of Nations, ed. C.H. Alexandrowicz (The Hague, 1972), pp. 177-96.

Cf. Morton White, The Philosophy of the American Revolution (New York, 1978), chap. 4.

Hans Welzel, 'Ein Kapitel aus der Geschichte der amerikanischen Erklärung der Menschenrechte (John Wise und Samuel Pufendorf)' in R. Schnur, ed. Zur Geschichte der Erklärung der Menschenrechte (Darmstadt, 1964).

Leonard Krieger, The Political Discretion. Pufendorf and the Acceptance of Natural Law (Chicago and London, 1965), pp. $259 \mathrm{ff}$. And for some due caution here: Diethelm Klippel, Politische Freiheit und Freiheitsrechte im deutschen Naturrecht des 18. Jahrhunderts (Paderborn, 1976), pp. 79-80, and the literature cited there.

9 Cf. C.G. Haines, The Revival of Natural Law Concepts (Cambridge, Mass., 1930).

10 There is a huge literature on this subject. Particularly useful are Erik Wolf, Grosse Rechtsdenker der deutschen Geistesgeschichte, 4. ed. (Tübingen 1963). Franz Wieacker, Privatrechtsgeschichte der Neuzeit, 2. ed., (Göttingen, 1967), Vierter Teil. Ernst Reibstein, 'Deutsche Grotius-Kommentatoren bis zu Christian Wolff', Zeitschrift für ausländisches öffentliches Recht und Völkerrecht, 15 (1953-54), pp. 76-102. Diethild Maria Meyring, Politische Weltweisheit, Studien zur deutschen politischen Philosophie des 18. Jahrhunderts, phil. Diss. (Münster, 
1965). And for German Aristotelianism, see P. Petersen, Geschichte der aristotelischen Philosophie im protestantischen Deutschland (Leipzig, 1921).

11 Cf. Christoph Link, Herrschaftsordnung und bürgerliche Freiheit Grenzen der Staatsgewalt in der älteren deutschen Staatslehre (Vienna, Cologne, Graz, 1979), chap. 1-2. Werner Schneiders, Naturrecht und Liebesethik. Zur Geschichte der praktischen Philosophie im Hinblick auf Christian Thomasius (Hildesheim and New York, 1971), p. 62 ff. Horst Denzer, Moralphilosophie und Naturrecht bei Samuel Pufendorf (Munich, 1972), passim.

12 Cf. Sieglinde C. Othmer, Berlin und die Verbreitung des Naturrechts in Europa. Kultur -und sozialgeschichtliche Studien zu Jean Barbeyracs Pufendorf -Übersetzungen und eine Analyse seiner Leserschaft (Berlin, 1970).

13 Cf. Alfred Dufour, 'Die Ecole romande du droit naturel - ihre deutschen Wurzeln', in Hans Thieme et al, eds., Humanismus und Naturrecht in Berlin -Brandenburg - Preussen (Berlin and New York, 1979), pp. 133-43, and the literature cited there.

14 Othmer, op.cit.; and Klaus Luig's review of Othmer in Tijdschrift voor Rechtsgeschiedenis, XX, 197.

15 Othmer op.cit. pp. 146-49.

16 Cf. Thomas Mautner, 'Kant's Relation to the Natural Law Tradition', Archiv für Rechts - und Sozialphilosophie, Supplementa, vol. I, Part 1, 'Contemporary Conceptions of Law' (9th World Congress, 1979), 1982. Christian Ritter, Der Rechtsgedanke Kants nach den Frühen Quellen (Frankfurt a.M., 1971), esp. chap. 2. Werner Busch, Die Entstehung der kritischen Rechtsphilosophie Kants 1762-1780 (Berlin and New York, 1979), esp. pp. $38 \mathrm{ff}$.

17 Cf. Klippel, Politische Freiheit, pp. 196-97.

18 I am here greatly indebted to Klippel, chap. 8.

19 Klippel, pp. 178-79.

20 For a stimulating programmatic consideration of this, see J.G.A. Pocock, 'Virtues, Rights, and Manners. A Model for Historians of Political Thought', Political Theory, 9 (1981), pp. 353-68.

21 Cf. Duncan Forbes. Hume's Philosophical Politics (Cambridge, 1975), chap. 1; 'Hume's Science of Politics', in G.P. Morice, ed., David Hume, Bicentenary Papers (Edinburgh, 1977), pp. 49-50; Natural Law and the Scottish Enlightenment', in R.H. Campbell and A.S. Skinner, eds., The Origins and Nature of the Scottish Enlightenment, pp. 186-204.

22 Cf. James Moore, and S.M. Silverthorne 'Gershom Carmichael and the Natural Jurisprudence Tradition in Eighteenth-Century Scotland', in I. Hont and M. Ignatieff, eds., Wealth and Virtue: the Shaping of Scottish Political Economy (Cambridge, 1983), pp. 73-87; Natural Sociability and Natural Rights in the Moral Philosophy of Gershom Carmichael' in V. Hope, ed., Philosophers of the Scottish Enlightenment (Edinburgh, 1984); J. Moore, 'Locke and the Scottish Jurists', in Gordon Schochet, ed., John Locke and the Political Thought of the 1680's (forthcoming). D.N. MacCormick, 'Law and Enlightenment', and T.D. Campbell, 'Francis Hutcheson: 'Father' of the Scottish Enlightenment', in R.H. 
Campbell and A.S. Skinner, eds., The Origins and Nature of the Scottish Enlightenment, pp. 167-185. Forbes, op.cit.. K. Haakonssen, The Science of a Legislator. The Natural Jurisprudence of David Hume and Adam Smith (Cambridge, 1982); 'What Might Properly Be Called Natural Jurisprudence?', in R.H. Campbell and A.S. Skinner, eds., op.cit., pp. 205-225; 'Hugo Grotius and the History of Political Thought', Political Theory, 13 (1985). H. Medick, Naturzustand und Naturgeschichte der bürgerlichen Gesellschaft. Die Ursprünge der bürgerlichen Sozialtheorie als Geschichtsphilosophie und Sozialwissenschaft bei Samuel Pufendorf, John Locke und Adam Smith (Göttingen, 1973).

23 Concerning Reid's manuscript lectures, see D.F. Norton, 'Reid's Abstract of the Inquiry into the Human Mind', in S.F. Barker and T.L. Beauchamp, eds., Thomas Reid: Critical Interpretations (Philadelphia, 1976), pp. 125-32. These lectures are presently being prepared for publication by a team of editors under the leadership of J.C. Stewart-Robertson, in conjunction with whom the present author is editing the lectures on jurisprudence and politics.

24 James Beattie, Elements of Moral Science, 2 vols. (Edinburgh, 1790-93).

25 Adam Ferguson, Institutes of Moral Philosophy (Edinburgh, 1773); Principles of Moral and Political Science, 2 vols. (Edinburgh, 1792). There is no reliable treatment of Ferguson's natural law position.

26 Cf. K. Haakonssen, 'Natural Justice. The Development of a Critical Philosophy of Law from David Hume and Adam Smith to John Millar and John Craig', Ph.d., Edinburgh, 1978, chap. 4.

27 Cf. K. Haakonssen, 'Dugald Stewart's Differences with Adam Smith in Moral Philosophy', in V. Hope, ed., Philosophers of the Scottish Enlightenment (Edinburgh, 1984), pp. 211-32.

28 Cf. Thomas Brown, Lectures on the Philosophy of the Human Mind, 4 vols. (Edinburgh, 1820), IV, pp. 183-398.

29 Cf. James Mackintosh, A Discourse on the Law of Nature and Nations (1799), in The Miscellaneous Works of the Right Honourable Sir James Mackintosh, 3 vols. (London, 1846), vol. 1.

30 Forbes, 'Natural Law and the Scottish Enlightenment', pp. $187 \mathrm{ff}$.

31 MacCormick, 'Law and Enlightenment'. And for a very useful survey of European institutionalist writers, see $\mathrm{K}$. Luig, Institutionenlehrbücher des nationalen Rechts im 17. und 18. Jahrhundert,' Jus Commune, III (1970), pp. 64-97.

32 J.G. Heineccius, A Methodical System of Universal Law: or the Law of Nature Deduced from Certain Principles and applied to Proper Cases, translated and illustrated with Notes and Supplements by George Turnbull, 2 vols. (London, 1741). - Cf. also Ernst Reibstein, 'J.G. Heineccius als Kritiker des grotianischen Systems', Zeitschrift für ausländisches öffentliches Recht und Völkerrecht, 24 (1964), pp. 236-64.

33 MacCormick, op.cit., p. 154.

34 For a few remarks on this, see Klippel, Politische Freiheit, pp. 182-83.

35 Cf. Klippel, op.cit., chap. 8; and M. Stolleis, Staatsraison, Recht und Moral in philosophischen Texten des späten 18. Jahrhunderts (Meisenheim am Glan, 1972); 
Über die Verbindung der Moral mit der Politik. Ein Beitrag zur Spätphase der Aufklärungsphilosophie in Deutschland', Archiv für Rechts - und Sozialphilosophie, 55 (1969), pp. 269-77.

36 Ibid.

37 The following three paragraphs derive from my 'Hugo Grotius and the History of Political Thought'.

38 Hugo Grotius, De iure belli ac pacis libri tres, 2 vols., translation [in vol. II] by F.W. Kelsey et al. (Oxford, 1913 and 1925), vol. II, Book I, chapter 1, section iv. (The book, chapter, section and paragraph numbering is the same in the Latin and the English texts; in the following I therefore exclude the volume-indication. Except in a couple of cases, which are noted, I have followed Kelsey's awkward translation). Cf. Marcel Thomann: 'Pour Aristote, les Romains de l'époque classique et Saint-Thomas le jus est l'égal, la res justa, l'objectum justitiae, l'id quod justum est. Ces autorités ignorent un 'droit' qui soit pouvoir, liberté, volonté ou faculté de l'individu. Dans les relations de la cité, il y a des personnes et des choses; et la jurisprudence, dit Ulpien, est la science des choses divines et humaines, et spécialement du justum et de l'injustum. La justice consiste à accorder à chaque chose sa place dans un monde harmonieux, où règne un juste universel donné par la nature.' 'Christian Wolff et le droit subjectif', Archives de philosophie du droit, 9 (1964), p. 154.

39 On the suum, see De iure, I, I, v. On the original form of suum and its conventional extension, ibid. II, II, ii.

40 For Grotius' characterisation of ius in terms of that which is not iniustum, see De iure, I, I, iii, I.

41 See Hägerström, Recht, Pflicht und bindende Kraft des Vertrages nach römischer und naturrechtlicher Anschauung, ed. Karl Olivecrona, in Skrifter utgivna av K. Humanistiska Vetenskapssamfundet $i$ Uppsala, 44:3 (Stockholm and Wiesbaden, 1965), pp. 53-54; and Karl Olivecrona, Law as Fact (2. ed., London, 1971), pp. 276-77.

42 See my discussion of Smith's theory in The Science of a Legislator, pp. $99 \mathrm{ff}$. and the references given there.

43 See Olivecrona, 'Die zwei Schichten im naturrechtlichen Denken'.

44 The most central discussions of this are in S. Pufendorf, Of the Law of Nature and Nations. Eight Books. Translated by Basil Kennet (3. ed., London, 1719), Book I, Chapter ii, Section 6, and Book II, Chapter iii, Section 4.

45 Hobbes is discussed throughout Law of Nature. For the present context see esp. I, vi, 4; I, vii, 13; and II, ii, 3 (in this last paragraph Pufendorf also attacks Spinoza).

46 See Law of Nature, I, i.

47 See Law of Nature, I, vi. The presentation of this is clear in De officio hominis et civis juxta legem naturalem libri duo, 2 vols., translation [in vol. II] by F.G. Moore (New York, 1927), Book I, Chapter ii.

48 For the basic principle, see De Officio, I, ix, and Law of Nature, III, ix-ix; these chapters are then followed by extensive discussions of the institutional consequences of the undertaking of obligations. 
49 The basis for this is also contractual. For the division of man's moral states into natural and adventitious, see De Officio, II, i, 2, and Law of Nature, I, i, 7. The three classes of adventitious states are those of marriage and the family (De Officio, II, ii-iii; Law of Nature, VI, i-ii); the master-servant relationship (De Officio, II, iv; Law of Nature, VI, iii); and civil society (De Officio, II, v-xviii; Law of Nature, Books VII-VIII).

50 It is necessary to read both the discussion of law and obligation in general and of natural law and its obligation (Law of Nature, I, vi, and II, iii; and cf. I, vii, 15; De Officio, I, ii-iii); see esp. Law of Nature, I, vi, 4.

51 J.G. Heinecci, Praelectiones academicae in Hugonis Grotii De Jure Belli et Pacis libros tres (1744) (Venice, 1771), pp. 14-15, quoted here from E. Reibsten, 'J.G. Heineccius als Kritiker des grotianischen Systems', Zeitschrift für ausländisches öffentliches Recht und Völkerrecht, 24 (1964), p. 248.

52 Law of Nature, I, vi, 3.

53 The following three paragraphs derive from my 'Hugo Grotius and the History of Political Thought'.

54 I am here indebted to Schneiders, Naturrecht und Liebesethik, pp. 64-65.

55 See Forbes, Hume's Philosophical Politics, pp. 41ff., and cf. his Natural Law and the Scottish Enlightenment', pp. 192-93.

56 A few very different examples: Johann Sauter, Die philosophischen Grundlagen des Naturrechts. Untersuchungen zur Geschichte der Rechts und Staatslehre (Frankfurt a.M., 1966 (1932)), pp. 91 ff.; A.H. Chroust, 'Hugo Grotius and the scholastic natural law tradition', The New Scholasticism, XVII (1943), pp. 101-133; John Finnis, Natural Law and Natural Rights (Oxford, 1980), pp. 43-44 and 54. - Cf. also the discussions of M.B. Crowe, The Changing Profile of the Natural Law (The Hague, 1977), pp. 223-28, and in A. Nussbaum, A Concise History of the Law of Nations (New York, 1954), pp. 296-306.

57 De iure, Prolegomena 11.

58 There is a huge literature on this topic. Some of it is discussed in the works referred to in note 56 above. The most recent monograph in English on Grotius does not rise above this; see C.S. Edwards, Hugo Grotius. The Miracle of Holland. A Study in Political and Legal Thought (Chicago, 1981), pp. $48 \mathrm{ff}$.

59 J. Finnis, Natural Law and Natural Rights.

60 Law of Nature, II, iii, 19.

61 Ibid.

62 See esp. Law of Nature, II, iii, 20 (cf. ibid., I, iii, 3); and De Officio I, iv, 8 (cf. ibid., pp. vi-vii).

63 G.W. Leibniz, 'Opinion on the Principles of Pufendorf', in The Political Writings of Leibniz, ed. P. Riley (Cambridge, 1972), pp. 73-74. Cf. the fine discussion by Moore and Silverthorne, 'Gershom Carmichael and the natural jurisprudence tradition in eighteenth-century Scotland', pp. 77-78, to which I am greatly indebted.

64 De Officio, pp. vii-viii; and Law of Nature, I, vi, $6 \mathrm{ff}$. 
65 See D.N. MacCormick, 'Law and Enlightenment', p. 154.

66 De Officio, I, ii, 11.

67 Law of Nature, I, vii, 3-4. In De Officio (i, ii, 13) Pufendorf's discussion is complicated by an attempt to distinguish good actions from just actions on the basis that the latter in addition to being in accordance with law must involve 'a regard for those toward whom the action goes out'.

68 Cf. Schneiders, Naturrecht und Liebesethik, pp. 70-74.

69 There is a brief interesting discussion of Cumberland and Hutcheson in this connection by D.D. Raphael, 'Bentham and the Varieties of Utilitananism, The Bentham Newsletter, No. 7 (1983), pp. 5-6. The only philosophically satisfactory discussion of Carmichael is in the two previously mentioned articles by Moore and Silverthorne, which have helped me a great deal, but see also J. McCosh, The Scottish Philosophy (1875) (Hildesheim, 1966), pp. 36-46; W.L. Taylor, 'Gershom Carmichael: A Neglected Figure in British Political Economy', South African Journal of Economics, 13 (1955), pp. 251-55; and especially Hans Medick, Naturzustand und Naturgeschichte der bürgerlichen Gesellschaft, pp. 299-305.

70 The following is based upon Carmichael's Supplements to his edition of Pufendorf: S. Puffendorfii De Officio Hominis et Civis juxta Legem Naturalem, Libri Duo. Supplementis et Observationibus in Academicae Juventutius usum auxit et illustravit Gerschomus Carmichael (Basel, 1739). Here Supplementum I, sects. 1-9, and Supplemtum II, sect. 3.

71 ibid., Supplementum I, sects. 10 and 19-20; Supplementum II, sects. 3-5.

72 ibid., Supplementum I, sects. 19-20.

73 Read ibid., Supplementum I, sect. 10, Supplementum II, sects. 1, 3, and 5, together.

74 ibid., Lectori Benevolo S.P.D. [Saluto Pro Deo] Gerschomus Carmichael, pp. 7-8 ('atque adeo Juris Naturalis Scientiam, quantumvis diversam ab Ethica, quae in Scholis dudum obtinuerat, prae se ferret faciem, non esse, quod ad scopum \& rem tractandam, vere aliam Disciplinam, sed eandem rectius duntaxat \& solidius traditam, ita ut, ad quem prius male collineaverat, tandem reipsa feriret scopum.'); cf. pp. 16-17. See also the discussion in Moore and Silverthorne, 'Gershom Carmichael and the natural jurisprudence tradition in eighteenth-century Scotland', pp. 77-80.

75 The following is based on ibid., Supplementum II, sects. 6-17.

76 The crucial passages are ibid., sects. 14-17.

77 T.D. Campbell, 'Francis Hutcheson: 'Father' of the Scottish Enlightenment', R.H. Campbell and A.S. Skinner, eds., The Origins and Nature of the Scottish Enlightenment, p. 171.

78 See Aristotle, Nicomachaen Ethics, translated and introduced by W.D. Ross (London 1959), $1130^{\mathrm{a}} 8-1131^{\mathrm{a}} 1$.

79 The rest of this paper derives from my 'Hugo Grotius and the History of Political Thought'. 
De iure, I, I, iv-v and vii-viii.

81 ibid., Prolegomena, sect. 8. The following quotation from Porphyry is added for support: 'Justice consists in the abstaining from what belongs to others, and in doing no harm to those who do no harm.'

82 See e.g. ibid., II, XVII, ii.

83 See Alf Ross, Kritik der sogenannten praktischen Erkenntnis. Zugleich Prolegomena zu einer Kritik der Rechtswissenschaft (Copenhagen and Leipzig, 1933), pp. 231-45.

84 Pufendorf, Law of Nature, I, vii, 7-8.

85 ibid., II, VI, 5; see in general ibid., 5-8.

86 Tully, Discourse on Property, p. 93; see also Tully's general discussion of natural law theory, pp. 80-94.

87 Tully's powerful study has suggested that this kind of interpretation of Locke is entirely misconceived, as Locke did not operate with rights as the moral power to exclude others from consideration in our use of a world which was given to each of us equally (negatively in common) - a concept which for Pufendorf and his followers seemed to lead to the need for a positive supplement, viz. the imperfect 'right' to be included after all. By contrast, it is suggested, Locke exploited the Thomistic tradition to construct the idea of rights as an entitlement ordered by divine natural law to be included in the moral considerations of others when using the world which was given to us jointly (in positive community) to preserve. And according to Tully this leads in some respects to a much more 'radical' political theory than the one we are accustomed to ascribe to Locke. - Whether or not this is the correct reading of Locke is, however, not our present concern, for the eighteenth century - and especially the Scottish thinkers dealt with below - seemed on the whole to read Locke in the light of Grotius and Pufendorf, and indeed in various respects they used him to improve on these (see Moore, 'Locke and the Scottish Jurists'.)

88 I here gloss over the translateability of rights-language and virtue-language. Concerning Smith, see my The Science of a Legislator, pp. 99-100, for brief comment. - The short sketch here of Hume and Smith is based on the argument in this book. Its motto could be Hume's dictum about his own endeavours: This theory concerning the origin of property, and consequently of justice, is, in the main, the same with that hinted at and adopted by Grotius.' (Hume, An Enquiry Concerning the Principles of Morals, ed. L.A. Selby-Bigge, revised by P.H. Nidditch, (Oxford, 1975), p. 307.

89 Francis Hutcheson, A System of Moral Philosophy, 2 vols. (London, 1745), in Collected Works of Francis Hutcheson, fascimile edition prepared by Bernhard Fabian, 7 vols. (Hildesheim, 1969), vols. 5-6 [I employ the volume numbers of the original edition, i.e. I and II], vol. I, 253; and cf. A Short Introduction to Moral Philosophy (Glasgow, 1747), in Collected Works, vol. 4, 118-20, and An Inquiry into the Original of our Ideas of Beauty and Virtue, The Fourth Edition (London, 1738), pp. 277-78. - Cf. the excellent short sketch of the connections between Hutcheson's moral and political philosophy, in Campbell, 'Francis Hutcheson: 'Father' of the Scottish Enlightenment'; and Raphael, 'Bentham and the Varieties of Utilitarianism', pp. 5-6. 
90 Introduction, pp. 122-23; cf. System, I, 262-63. Concerning perfect and imperfect rights, see Introduction, pp. 141-46; System, I, 257-59; Inquiry, 278-80. - Hutcheson also adopts the category of 'external rights', which are simply perfect ('legal') rights which are immoral: System, I, 259-60; Introduction, p. 123; Inquiry, pp. 281-82.

91 Introduction, p. 120; cf. System, I, 273-74.

92 System, I, 260; Introduction, p. 123; Inquiry, p. 282.

93 See Introduction, chapter 8, and System, Book III, chapter 9.

94 Concerning the object and method of law: An Essay on the History of Civil Society (Edinburgh, 1767), ed. and introd. by D. Forbes (Edinburgh, 1966), pp. 154-67; Institutes of Moral Philosophy, The Second Edition (Edinburgh, 1773; fascimile edition, New York and London 1978), pp. 172-73; Principles of Moral and Political Science, 2 vols. (Edinburgh, 1792; fascimile edition, Hildesheim and New York, 1975), II, 179-83 and 315-16. - Concerning the system of rights: Institutes, pp. 174-202; Principles, II, chapter 3. - Concerning negative community: Principles, II, 192-93.

95 Principles, II, 257-92, esp. 270-92 (the most central principles are at 284-88): Institutes, pp. 203-208.

96 Principles, II, 315-20; cf. Institutes, pp. 213-14. - One of the cardinal virtues is, of course, justice, and Ferguson underlines that he has some distinction between law and morality by distinguishing sharply between justice as it is enforced by law and as it is exercised 'freely' as a virtue (Principles, ibid.). This is also the reason why he feels free to use 'justice' and 'benevolence' interchangeably in the classical manner, when he discusses the cardinal virtues elsewhere - but it is certainly a confusing usage (see Principles, II, 43-44 and 108-111).

97 Principles, II, 316.

98 Although he does say that those in dire need and without the ability of self-help have a claim not only upon the humanity and compassion of the rich, but upon the justice and good policy of their country also.' Principles, II, 372; and cf. Institutes, p. 212. 